\title{
Alternative n-3 PUFAs Sources in Central European Diet before Westernization - Case Report from Poland
}

\author{
Kamil K. Hozyasz ${ }^{1}$ \\ ${ }^{1}$ Department of Paediatrics, Institute of Mother and Child, Warsaw, Poland \\ Correspondence: Kamil K. Hozyasz, Dept. of Pediatrics, Institute of Mother and Child, 17a Kasprzaka Str., \\ Warsaw 01-211, Poland. Tel: 48-223-277-190.E-mail: khozyasz@verco.com.pl; kamil.hozyasz@imid.med.pl
}

Received: January 5, 2013 Accepted: February 13, 2013 Online Published: February 27, 2013

doi:10.5539/jfr.v2n2p29 URL: http://dx.doi.org/10.5539/jfr.v2n2p29

\begin{abstract}
Knowledge of the former food system of a population provides essential information for a better understanding of the nature of nutritional problems. This paper reports on efforts to determine possible n-3 PUFAs sources in the non-westernized diet of a peasant family who lived in an economically underdeveloped region of Poland (the White Forest) in the early 1970s. The observations presented herein led to the recognition of the potential use of wild green plants, animal-based products from extensive agriculture (eggs, diary, rabbit meat) and aquatic food (in a direct way e.g. from the anadromous fish Vimba vimba and indirectly via poultry and pig feed e.g. freshwater mussels) for inland populations with a lack of oily marine fish intake. Directions for future research on foodways as well as applications in fields concerning dietary change and nutritional education have also been suggested.
\end{abstract}

Keywords: PUFAs, food habits, fish intake, migratory fish, Anodonta anatina, ethnography

\section{Introduction}

There are two polyunsaturated fatty acids (PUFAs), linoleic acid (LA; 18:2n-6) and $\alpha$-linolenic (ALA; 18:3n-3), that cannot be synthesized de novo in humans and which are therefore designated as essentially fatty acids. Polyunsaturated fatty acids are classified as n-3 or n-6 on the basis of the location of the first double bond three or six carbons away from the methyl end of the molecule. $\alpha$-Linolenic acid which is obtained from green leafy vegetables, walnuts, flaxseed and rapeseed, can further be elongated, although not efficiently, to eicosapentaenoic acid (EPA; 20:5n-3) and decosahexaenoic acid (DHA; 22:6n-3) (Kochbar, 2002; Simopoulos, 2004; Pieniak, Verbeke, Perez-Cueto, Brunso, \& De Henauw, 2011). The poor conversion of ALA to DHA in modern humans has to be taken as proof of the necessity to obtain preformed DHA from our diet (Pieniak, Verbeke, Perez-Cueto, Brunso, \& De Henauw, 2011). Marine fish oils are the richest dietary source of EPA and DHA. An increased intake of EPA and DHA is reported to have beneficial effects in a variety of degenerative disorders, for example cardiovascular pathologies, as well as pregnancy outcomes (Marangoni et al., 2007; Pieniak, Verbeke, Perez-Cueto, Brunso, \& De Henauw, 2011). An adequate supply of DHA is critical for brain development and growth. Virtually every professional association representing paediatricians supports the inclusion of DHA in infant formulas.

Poland belongs to the group of countries with a poor tradition of eating fish (Pieniak, Verbeke, Perez-Cueto, Brunso, \& De Henauw, 2011). Attempts to increase the consumption of oily marine fish appear to be undermined by the lack of these fish in the cultural background, poor levels of taste acceptability, as well as concerns about contamination with methyl mercury and other toxicants (Pieniak, Verbeke, Perez-Cueto, Brunso, $\&$ De Henauw, 2011). Therefore, recognition of the importance of n-3 PUFAs has focused greater attention on the dietary supply of these fatty acids from sources other than marine fish. It appears that looking for the optimal diet has come full circle, with an increased interest emerging in the positive aspects of ancestral diets (Cordain, 2002; Simopoulos, 2004; Manios, Detopoulou, Visioli, \& Galli, 2006). The aim of present study was to identify potential sources of n-3 PUFAs in the diet of a peasant family settled in an underdeveloped region of Poland before westernization.

\section{Material and Methods}

This study presents observations made by the author during his summer investigations during the years 
1971-1973 of a peasant family in the rural Branszczyk village in the economically underdeveloped White Forest (Hozyasz, 2007). This village is located in north-eastern Poland by the river Bug. Branszczyk has existed since at least the thirteenth century. In the nineteenth and early twentieth century's the region comprised a reservoir of rural people living on the verge of biological existence (Hozyasz, 2007). In the 70s of the last century transportation was very scarce, thus the village population was partially isolated and had no easy access to commodities trading in marine fish. The family investigated consisted of a couple whose two adult children had migrated to the town. The family owned a four-room house, a barn, a cowshed joined to a poultry house, a small pigsty, agricultural land of approximately 4 ha, including arable land and a water meadow, a small orchard, and a small part of a moist forest with alders (Alnus glutinosa), pines (Pinus sylvestris), willows (Salix alba), apple trees (Malus domestica, M. sylvetris) and bird cherries (Padus avium). The objective of the investigation was to determine sources of self-produced or self-collected food. Using nutritional data from the literature, foods were defined as important n-3 PUFAs sources if they were estimated to be higher in n-3 PUFAs compared to similar alternatives.

\section{Results and Discussion}

The family was likely to believe it had restricted access to high quality food resources in the nearest shops and thus tried to be self-sufficient in food acquisition. The foods produced and collected are shown in Table 1. Unfortunately exact data on food intake were not recorded.

Table 1. Food consumed that was self-produced or self-collected by the peasant family under observation

\begin{tabular}{lll}
\hline Food group & Source details & Animal feeding and culinary practices \\
\hline Flesh & Poultry: chickens, geese & Chickens and geese were fed on various types \\
& of fresh green grass and wild plants including \\
& liverworts and mosses growing near water, and \\
& fresh fruits (Ribes nigrum, $R$. rubrum) \\
& supplemented with oat or barley flour. The \\
& poultry also ate insects of all kinds and cooked \\
& bivalves (Anodonta anatina, A. cygnea, \\
& Pseudoanadonta complanata) with potatoes \\
& $2-4$ times per month.
\end{tabular}

Pork

Rabbit

Fish Lean: pike (Esox lucius), Europen perch (Perca fluviatilis), common roach (Rutilus rutilus), common rudd (Scardinius erythrophtalamus), freshwater bream (Abramis brama), white bream (Blicca bjoerkna)

Fatty: tench (Tinca tinca), catfish (Silurus glanis), vimba (Vimba vimba), eel (Anguilla anguilla)

Eggs Hens eggs

Milk and dairy Cow's milk, cream, curd, quark cheese
Pigs were generally fed potatoes supplemented with whole grain flour. They also received weeds or wild plants (Urtica dioica, Symphytum officinale, Trifolium spp., Rumex hydrolapathum, Equisetum spp.) almost every day. They were also fed on cooked bivalves 2-4 times per month.

Rabbits were generally fed grass, wild greens, weeds, and apples rather than grains.

Pike, common roach, and white bream were the commonly caught species.

Fatty fish, boiled with vegetables or fried, were especially valued.

From free-range hens (mostly of the native Polish breed the green-legged hen / Zielononóżka kuropatwiana, known for its ability to self-feed).

Intake of botanically diverse forage: different 
products

$\begin{array}{ll}\begin{array}{l}\text { Grain products } \\ \text { and other } \\ \text { starchy foods }\end{array} & \text { Rye flour, oat flakes } \\ \text { Visible fat } & \text { Potatoes fat, lard } \\ & \text { Goose fat* } \\ & \text { Flaxseed oil (linola oil) } \\ & \\ & \text { Cow's milk butter }\end{array}$

Fruits in season Extensively cultivated: apples, pears, cherries, plums, blackcurrants, redcurrants, whitecurrants, gooseberries, raspberries.

Wild fruits: apples, blueberries, blackberries, elderberries.

Vegetables Cultivated: carrot, parsley, beetroot, cabbage, lettuce, cucumber, tomato, pumpkin, pea, white bean, onion, garlic, dill.

Wild greens: sorrel (Rumex acetosa), wood sorrel (Oxalis acetosella).

Wild flowers

Black locust (Robinia pseudoaccacia), comfrey (Symphytum officinale), white deadnettle (Lamium album).

Nuts Walnuts, hazelnuts.

Wild seasoning Horseradish, roots and leaves plants

(Armoracia rusticana).

Sweet flag, rhizomas and leaves (Acorus calamus).

Juniper, pseudo-fruits (Juniperus communis).

Medicinal Common lime (Tilia europaea), tansy herbs (Tanacetum vulgare), St. John's wort (Hypericum perforatum), corn minth (Mentha arvensis), German chamomile (Chamomilla recutita).

Wild Penny bun (Boletus edulis) and other mushrooms Boletaceae, sticky bun (e.g. Suillus luteus), golden chantarelle (Cantharellus cibarius), scotch bonnet (Marasmius oreades), saffron milk cap (Lactarius deliciosus). grasses, white and red clover, leaves and young shoots of small trees (no maize or silage).

Oat flakes with cow's milk constituted the typical evening dish.

The bulk of starchy food was provided by cooked potatoes as a part of lunch.

The main fat used for frying, as well as for cooked potatoes and bread.

This type of fat was mainly added to vegetable soups.

Mainly used for frying potato pancakes (like the German Kartoffelpuffer) or apple pancakes (like the Scottish dropped scones).

For bread, sauces, scrambled eggs.

Apple - most popular dried fruit used as a snack.

Blueberries - for soups or drying.

Elderberries - for juice or dried for infusions (used as a remedy for common colds).

Interestingly only the young, delicate leaves (not the dark-green leaves) of lettuce were eaten.

Sorrel - cooked in soups.

Wood sorrel - served as a snack.

For salads or the flowers were sucked for nectar.

Two large trees of Juglans regia in the garden; however, the species is rarely cultivated in the village.

Horseradish - grated roots used as a meat condiment; roots and leaves used in the pickling of various vegetables and for the fermentation of cucumbers.

Sweet flag - a fragrant base for pear compote Juniper - used as a seasoning for red meat Infusions from common lime were frequently consumed when black tea was unavailable.

Mushrooms were preserved for winter by drying, pickling or fermenting.

Fried saffron milk caps or sticky buns with cream were especially valued.

\footnotetext{
*Polish breeds of geese are known for their lower susceptibility to liver steatosis and high levels of production of subcutaneous and abdominal adipose tissues (Poujardieu et al., 1994).
} 
Scientific interest in the potential beneficial effects of an optimal PUFAs composition of the diet has increased (Simopoulos, 2004; Pieniak, Verbeke, Perez-Cueto, Brunso, \& De Henauw, 2011). This interest is mainly focused on the intake of oily marine fish. In contrast to this, the present study focuses on different, potential sources of n-3 PUFAs in the traditional diet of a Polish peasant family living in an economically underdeveloped area 40 years ago, when there was no habit of buying marine fish.

For many low- and middle-income people the main sources of n-3 PUFAs were cereals and vegetable oils. Rye and oats were the main grain foods in the presented family. Their composition of PUFAs is favourable compared to other grain staple foods (Leinonen, Poutanen, \& Mykkanen, 2000; Gambuś et al., 2011). Oat grain is characterized by an especially valuable chemical composition, and the combination of nutritional compounds present in this cereal makes it a beneficial constituent of human and poultry diets (Gambuś et al., 2011). Flaxseed oil has an extremely high ALA content (Kochbar, 2002). However, it was only pressed occasionally and butter and lard came in first position in the cuisine of the family investigated. The availability of oils and animal fat was the primary reason why this sort of fat was choosen for cooking and frying. The family relied on nuts, dried cultivated or wild apples and to lesser extent wild flowers and wood sorrel as snacks. Epidemiological studies showed that frequent nut consumption is associated with a significant reduction in the risk of atherosclerosis (Marangoni et al., 2007). Walnuts appear to be an important source of ALA (Marangoni et al., 2007).

Animal-based foods, including milk, eggs, poultry, meat and fish, could be important sources of n-3 PUFAs. However, the exact content of PUFAs will depend on the feed of the animals. The industrial production of animal feeds rich in grains containing n-6 PUFA is leading to the production of human food rich in n-6 and poor in n-3 PUFAs (Simopoulos \& Salem, 1992; Simopoulos, 2004). A study of Simopoulos and Salem (1992) showed that the egg yolk of hens fed under conditions similar to those observed in Branszczyk is rich in n-3 PUFAs and may contain several times more DHA compared to standard supermarket eggs. On the farm investigated the semi-wild hens had unrestricted free access to grass and moist forest, and thus the possibility of feeding on wild plants, including lower plants such as liverworts, mosses and ferns, as well as invertebrates, which are good sources of n-3 PUFAs (Simopoulos, 2004). Cultivated plants contain fewer n-3 PUFAs than wild plants (Simopoulos, 2004). In nutritional terms, human physiology evolved in the context of wild plants and animals. The consumption of eggs and meat from free-range chickens could make a nutritionally significant contribution to the population-wide intake of n-3 PUFAs, given the high consumption of poultry products by a wide sector of the population. However, it must be noted that currently the most popular free-range system is not organic but the backyard system, in which hens are kept in small flocks of 30-100 birds and mainly fed cereals (Krawczyk, 2009). It was reported that green-legged hens from organic farming system vs. backyard or intensive indoors system were characterized by the highest weight of yolk, the lowest cholesterol level in yolk, and the highest levels of micronutrients (Krawczyk, 2009). It should also be mentioned that, unfortunately, up to $30 \%$ of traditional poultry breeds are threatened with extinction and that $9 \%$ have already gone extinct (Sawicka, Brzezinska, \& Bednarczyk, 2011).

Plenty of studies have shown that cows pastured on botanically diverse forage at a young stage of maturity yield milk with an increased n-3/n-6 PUFA ratio and decreased saturated fatty acid contents (Harstad \& Steinshamn, 2010). Feeding cows on maize and silage resulted in decreased unsaturated/saturated fatty acid ratios in their milk (Harstad \& Steinshamn, 2010). In monogastric animals such as pigs, poultry and rabbits, the composition of fatty acids stored in adipose tissues largely reflects that of ingested lipids (Kouba \& Mourot, 2011). The fatty acid composition of rabbit meat seems to be negatively affected by the housing system based on small cages (Lazzaroni, Biagini, \& Lussiana, 2009). For this reason, choices regarding the ethical and responsible rearing of livestock are also very important (Sukkar, 2011).

Higher plants and animals are unable to effectively synthesize EPA or DHA. A variety of freshwater algae are important sources of n-3 PUFAs in different food chains (Ahlgren, Lundstedt, Brett, \& Forsberg, 1990). Freshwater bivalves feed on different strains of plankton, including algae, and therefore, they could be good examples of potential non-direct EPA and DHA sources in the traditional Polish diet (Bontes, Verschoor, Pires, van Donk, \& Ibelings, 2007). Currently, freshwater mussels are important dietary supplements for poor inhabitants of Asia. They are also used as poultry and fish feed (Baby, Hasan, Kabir, \& Naser, 2010). Linnaeus chose the word anatina (of ducks) to denote one species of freshwater mussel from the genus Anodonta because of the likelihood of its common usage in some regions of Europe to feed ducks and pigs (Valledor de Lozoya \& Araujo, 2011).

Generally, fish have a positive impact on the quality and nutritional enhancement of a family's diet, especially in children and pregnant women. The source of a fish supply varies with economical and ecological conditions. The 
family observed in the present study consumed fish from the Bug River at least twice monthly. Two fish species were particularly valued: catfish and, historically, vimba (Vimba vimba also called silver bream, zarthe), which was very common in the Bug River until the early 1960s and regarded as especially healthy for small children. Vimba is a rich source of n-3 PUFAs with the desired n-3/n-6 ratio (Kolakowska, Szczygielski, Bienkiewicz, \& Zienkowicz, 2000; Kalyoncu, Kissal, \& Aktumsek, 2009). It should be mentioned that vimba is an anadromous species which that most of its life in the sea and migrates to freshwater to breed. After spawning, vimba returns back to the sea. This fatty cyprinid is distributed throughout rivers running to the North, the Baltic, the Black and the Caspian Seas, and in lakes of western Turkey (landlocked lake populations). This fish species predominantly feeds on small molluscs and insect larvae. The second vimba species, $V$. melanops, is distributed throughout the northern Aegian basin (Hänfling, Dümpelmann, Bogutskaya, Brandl, \& Brändle, 2009). For a long time, vimba enjoyed the status of a very important fishery in Poland; however, nowadays it is seriously threatened with extinction in the country (Radwan, Girsztowtt, \& Kolejko, 2003; Hänfling, Dümpelmann, Bogutskaya, Brandl, \& Brändle, 2009; Psuty, 2010). Vimba is now also declining in number in the inland waters of Turkey because of over fishing (Okgerman, Elp, \& Yardimici, 2011).

Migratory fish are extremely susceptible to changes in environmental conditions. Populations of most of the 25 European anadromous fishes are reduced and need protection (Lassale, Crouzet, \& Rochard, 2009). One extreme case is the Atlantic sturgeon (Acipenser oxyrinchus), which only spawns in the large rivers running to the southern Baltic Sea. Historically, the main spawning grounds were located in Oder, as well as in Bug, Narew, San, and Wislok rivers, which belong to the Vistula River basin (Hoffmann, 2005; Kolman, Kapusta, Duda, \& Wiszniewski, 2011). Interestingly, from excavations dating back to the thirteenth and fourteenth centuries, sturgeons were thought to compromise $70 \%$ of the total protein consumption in fisheries settlements at the lower Vistula. Human activities (e.g. over fishing, land amelioration and deforestation within the watershed of rivers, leading to alterations in spring-water run-off and increased pollution/sediment transport) led to the disappearance of the sturgeon in Poland, where all catches of this species were banned in 1936 (the last sturgeon was recorded in Branszczyk 2 years later - personal communication). From an evolutionary point of view, the changes that have taken place in our environment, including lifestyle and dietary shifts, occurred at faster rate than the human genome could adapt to, and thus humans are still biologically adapted to the environments of their ancestors. Interestingly, in the literature the role of shore-based foods in human (brain) evolution is widely discussed (Langdon, 2006), but data on the (potential) role of anadromous fish transferring EPA, DHA, and iodine to inland human populations is missing.

The best-known diet of European origin producing health-promoting effects is the Mediterranean diet (Jackson \& Pellett, 2004; Simopoulos, 2004; Manios, Detopoulou, Visioli, \& Galli, 2006). Several components in the Mediterranean diet and also requirements linked to agriculture, such as the responsible rearing of livestock and respect for the seasons, have been underestimated, neglected or not properly underlined within existing popular guidelines (Manios, Detopoulou, Visioli, \& Galli, 2006; Sukkar, 2011). Recently, Manios et al. (2006) suggested that wild greens, snails and eggs from free-range hens could be a forgotten, missing part of the Cretan longevity puzzle and should be highlighted in dietary guidelines. Interestingly, the diet of the family investigated, who did not live in a Mediterranean region, contained good eggs, food based on animals consuming snails and bivalves, and soups prepared from wild plants at least once a week (e.g. sorrel puree soup, cream of pumpkin soup with wild mirabelles). Similar to the animals of Crete, green-legged hens and rabbits had grazed on wild greens and fruits rather than being fed (Simopoulos \& Salem, 1992). Finally, it is important to emphasize the fact that eggs are perfectly protected against the oxidative deterioration of n-3 PUFAs during their shelf life (Kochbar, 2002).

Available evidence suggests that in traditional agricultural communities a number of culinary habits and animal feeding practices may have evolved as adaptive strategies to buffer against a lack of access to oily marine fish, providing an alternative source of n-3 PUFAs. As far as the Spanish diet is concerned, fish holds a special position, the extent of which is not seen throughout the rest of the Mediterranean region (Manios, Detopoulou, Visioli, \& Galli, 2006). Humans can flourish on an extremely broad range of food items and cuisines. The dietary reconstruction presented herein may serve to draw attention to the fact that even indigenous foods from Central Europe might be important - and possibly overlooked - terrestrial sources of n-3 PUFAs. Moreover, we should entertain a more ecocentric perspective that acknowledges the extent to which the vicissitudes of humans and other species mutually affect the prospects of healthy survival for all (Zwart \& Penders, 2011).

\section{References}

Ahlgren, G., Lundstedt, L., Brett, M., \& Forsberg, C. (1990). Lipid composition and food quality of some freshwater phytoplankton for cladoceran zooplankters. Journal of Plankton Research, 12, 809-818. http://dx.doi.org/10.1093/plankt/12.4.809 
Baby, R. L., Hasan, I., Kabir, K. A., \& Naser, M. N. (2010). Nutrient analysis of some commercially important molluscs of Bangladesh. Journal of Scientific Research, 2, 390-396. http://dx.doi.org/10.3329/jsr.v2i2.3362

Bontes, B. M., Verschoor, A. M., Pires, L. M., van Donk, E., \& Ibelings, B. W. (2007). Functional response of Anodonta anatina feeding on a green alga and four strains of cyanobacteria, differing in shape, size and toxicity. Hydrobiologia, 584,191-204. http://dx.doi.org/10.1007/s10750-007-0580-2

Cordain, L. (2002). The Paleodiet. Hoboken: John Wiley \& Sons, Inc.

Gambuś, H., Gibiński, M., Pastuszka, D., Mickowska, B., Ziobro, R., \& Witkowicz, R. (2011). The application of residual oats flour in bread production in order to improve its quality and biological value of protein. Acta Scientiarum Polonorum - Technologia Alimentaria, 10, 313-325. http://www.food.actapol.net/issue3/volume2/4_3_2011.pdf

Hänfling, B., Dümpelmann, C., Bogutskaya, N. G., Brandl, R., \& Brändle, M. (2009). Shallow phylogeographic structuring of Vimba vimba across Europe suggests two distinct refugia during the last glaciation. Journal of Fish Biology, 75, 2269-2286. http://dx.doi.org/10.1111/j.1095-8649.2009.02415.x

Harstad, O. M., \& Steinshamn, H. (2010). Cow's diet and milk composition. In M.W. Griffiths (Ed), Improving the safety and quality of milk. Volume 1: Milk production and processing (pp 223-263). Cambridge: Woodhead Publishing Limited, CRC.

Hoffmann, R. C. (2005). A brief history of aquatic resource use in medieval Europe. Helgoland Marine Research, 59, 22-30. http://dx.doi.org/10.1007/s10152-004-0203-5

Hozyasz, K. K (2007). A persistance of tobacco smoking addiction in economically severly underdeveloped regions of Poland - the case of the Green Forest and White Forest. Przeglad Lekarski, 64, 913-914. http://www.wple.net/plek/numery_2007/numer-10-2007/913-914-hozyasz.pdf

Jackson, R. T., \& Pellett, P. L. (2004). Introductory observations: the region, nutrition, and health. Ecology of Food and Nutrition, 43, 3-16. http://dx.doi.org/10.1080/03670240490274057

Kalyoncu, L., Kissal, S., \& Aktumsek, A. (2009). Seasonal changes in the total fatty acid composition of vimba, Vimba vimba tenella (Nordmann, 1840) in Egirdir Lake, Turkey. Food Chemistry, 116, 728-730. http://dx.doi.org/10.1016/j.foodchem.2007.10.080

Kochbar, S. P. (2002). Sezame, rice-bran and flaxseed oils. In F. D. Gunstone (Ed.), Vegetable oils in food technology (pp 297-326). Oxford: Blackwell Publishing.

Kolakowska, A., Szczygielski, M., Bienkiewicz, G., \& Zienkowicz, L. (2000). Some of fish species as a source of n-3 polyunsaturated fatty acids. Acta Ichthyologica Piscatoria, 30, 59-70. http://www.aiep.pl/volumes/2000/0_2/pdf/30_2_06.pdf

Kolman, R., Kapusta, A., Duda, A., \& Wiszniewski, A. (2011). Review of the current status of the Atlantic sturgeon Acipenser oxyrinchus Mitchill 1815, in Poland: principles, previous experience, and results. Journal of Applied Ichthyology, 27, 186-191. http://dx.doi.org/10.1111/j.1439-0426.2011.01680.x

Kouba, M., \& Mourot, J. (2011). A review of nutritional effects on fat composition of animal products with special emphasis on n-3 polyunsaturated fatty acids. Biochimie, 93, 13-17. http://dx.doi.org/10.1016/j.biochi.2010.02.027

Krawczyk, J. (2009). Quality of eggs from Polish native Greenleg Partrige chicken-hens maintained in organic vs. backyard production systems. Animal Sciences Papers Reports, 27, 227-235. http://www.ighz.edu.pl/files/objects/2791/66/strona227-236.pdf

Langdon, J. H. (2006). Has an aquatic diet been necessary for hominin brain evolution and functional development? British Journal of Nutrition, 96, 7-17. http://dx.doi.org/10.1079/BJN20061805

Lassalle,. G., Crouzet, P., \& Rochard, E. (2009). Modelling the current distribution of European diadromous fishes: an approach integrating regional anthropogenic pressures. Freshwater Biology, 54, 587-606. http://dx.doi.org/10.1111/j.1365-2427.2008.02135.x

Lazzaroni, C., Biagini, D., \& Lussiana, C. (2009). Fatty acid composition of meat and perirenal fat in rabbits from two different rearing systems. Meat Sciences, 83, 135-139. http://dx.doi.org/10.1016/j.meatsci.2009.04.011

Leinonen, K. S., Poutanen, K. S., \& Mykkanen, H. M. (2000). Rye bread decreases serum total and LDL cholesterol in man with moderately elevated serum cholesterol. Journal of Nutrition, 130, 164-170. 
http://jn.nutrition.org/content/130/2/164.full.pdf + html

Manios, Y., Detopoulou, V., Visioli, F., \& Galli, C. (2006). Mediterranean diet as a nutrition education and dietary guide: misconceptions and the neglected role of locally consumed foods and wild green plants. Forum of Nutrition, 59, 154-170. http://dx.doi.org/10.1159/000095212

Marangoni, F., Colombo, C., Martiello, A., Poli, A., Paoletti, R., \& Galli, C. (2007). Levels of the n-3 fatty acid eicosapentaenoic acid in addition to those of alpha linolenic acid are significantly raised in blood lipids by the intake of four walnuts a day in humans. Nutrition, Metabolism and Cardiovascular Diseases, 17, 457-461. http://dx.doi.org/10.1016/j.numecd.2006.02.004

Okgerman, H., Elp, M., \& Yardimici, C. H. (2011). Growth, the lenght-weight relationship, and reproduction in vimba (Vimba vimba L.1758) sampled from an oligo-mesotrophic lake in northwest Anatolia (Turkey). Turkish Journal of Zoology, 35, 87-96. http://dx.doi.org/103906/zoo-0901-16

Pieniak, Z., Verbeke, W., Perez-Cueto, F. Brunso, K., \& De Henauw, S. (2011). Fish consumption and its motives in households with versus without self-reported history of CVD: a consumer survey from five Europen countries. BMC Public Health, 8, 306. http://dx.doi.org/10.1186/1471-2458-8-306.

Poujardieu, B., Rouvier, R., Rousselot-Pailley, D., Guy, G., Rosinski, A., \& Wezyk, S. (1994). Croissance et aplitude au gavage de 3 genotypes d'oies. Annales de Zootechnie, 43, 197-211.

Psuty, I. (2010). Natural, social, economical and political influences on fisheries : a review of the transitional area of the Polish waters of the Vistula Lagoon. Marine Pollution Bulletin, 61, 162-177. http://dx.doi.org/10.1016/j.marpolbul.2010.02.010

Radwan, S., Girsztowtt, Z., \& Kolejko, M. (2003). Ichthyofauna of the middle course of the river Bug. Acta Agrophysica, 1 , http://www.old.acta-agrophysica.org/artykuly/acta_agrophysica/ActaAgr_86_2003_1_1_153.pdf

Sawicka, D., Brzezińska, J., \& Bednarczyk, M. (2011). Cryoconservation of embryonic cells and gametes as a poultry biodiversity reservation method. Folia Biologica (Kraków), 59, 1-5. http://www.isez.pan.krakow.pl/journals/subscription.htm

Simopoulos, A. P. (2004). Omega-3 fatty acids and antioxidants in edible wild plants. Biological Research, 37, 263-277. http://dx.doi.org/10.4067/S0716-97602004000200013

Simopoulos, A. P., \& Salem, N. (1992). Egg yolk as a source of long-chain polyunsaturated fatty acids in infant feeding. American Journal of Clinical Nutrition, 55, 411-414. http://ajcn.nutrition.org/content/55/2/411.long

Sukkar, S. G. (2011). Mediterranean diet? no, thanks: Mediterranean lifestyle!. Mediterranean Journal of Nutrition and Metabolism, 4, 79-81. http://dx.doi.org/10.1007/s12349-011-0070-y

Valledor de Lozoya, A., \& Araujo, R. (2011). How the naiad was drawn : a pre-Linnean iconography of freshwater mussels. Malacologia, 53, 381-402. http://dx.doi.org/10.4002/040.053.0209

Zwart, H., \& Penders, B. (2011). Genomics and the ark - an ecocentric perspective on human history. Perspectives in Biology and Medicine, 54, 217-231. http://dx.doi.org/10.1353/pbm.2011.0019 